Review paper

\title{
The significance of reworked palynomorphs (middle Cambrian to Tournaisian) in the Visean Toca da Moura Complex (South Portugal). Implications for the geodynamic evolution of Ossa Morena Zone
}

\author{
Gilda Lopes $^{\mathrm{a}, \mathrm{b}}$, Zélia Pereira ${ }^{\mathrm{b}, *}$, Paulo Fernandes ${ }^{\mathrm{a}}$, Reed Wicander ${ }^{\mathrm{c}}$, João Xavier Matos ${ }^{\mathrm{d}}$, \\ Diogo Rosa ${ }^{\mathrm{e}}$, José Tomás Oliveira ${ }^{\mathrm{f}}$ \\ a CIMA - Centro de Investigação Marinha e Ambiental, Universidade do Algarve, Campus de Gambelas, 8005-139 Faro, Portugal \\ b LNEG-LGM, Rua da Amieira, Ap. 1089, 4466-901 S. Mamede Infesta, Portugal \\ c Department of Earth and Atmospheric Sciences, Central Michigan University, Mt. Pleasant, MI 48859, USA \\ d LNEG-LGM, Rua Frei Amador Arrais, 39 Apartado 104, 7801-902 Beja, Portugal \\ e GEUS - Nationale Geologiske Undersøgelser for Danmark og Grønland (GEUS), Division Petrology and Economic Geology, Øster Voldgade 10, København K 1350, Denmark \\ f LNEG-LGM, Estrada da Portela, Zambujal Apartado 7586, 2611-901 Amadora, Portugal
}

\section{A R T I C L E I N F O}

\section{Article history:}

Received 7 February 2013

Received in revised form 18 June 2013

Accepted 26 July 2013

Available online 15 August 2013

\section{Keywords:}

palynostratigraphy

reworked palynomorphs

Carboniferous

Paleozoic

Ossa Morena Zone

Variscan Orogeny

\begin{abstract}
A B S T R A C T
The $404.5 \mathrm{~m}$ deep SDJ1 borehole is located in the Jongeis mining sector of the Santa Susana Basin (SSB), and has been palynostratigraphically studied. The SSB is a Carboniferous coal-bearing basin developed along the suture contact between the Ossa Morena Zone (OMZ) and the South Portuguese Zone (SPZ).

The recovered palynologic assemblages are assigned to the NM Miospore Biozone of mid Visean age, with the lowermost $6.8 \mathrm{~m}$ of the borehole yielding an in situ miospore assemblage assigned to the SL Miospore Biozone of mid Moscovian age. All of the studied samples contained more than $90 \%$ of reworked palynomorphs ranging in age from the middle Cambrian to the early Tournaisian (0-397.7 m depth), with the first 6.8 m (397.7$404.5 \mathrm{~m}$ depth) yielding reworked palynomorphs from the middle Cambrian to the mid Moscovian. This particular palynologic signature provides further evidence for the interpretation of the reworked palynomorphs in the Toca da Moura Complex (TMC) and its importance in the geodynamic evolution of the OMZ, regarding the probable provenance areas of the reworked palynomorphs within the OMZ and SPZ. Six reworked sub-assemblages were discriminated: i. middle to (?) upper Cambrian; ii. Lower to Middle Ordovician; iii. middle to upper Silurian; iv. Lower Devonian; v. Upper Devonian and vi. lower Carboniferous.

From the study of the palynomorph assemblages (both in situ and reworked) recovered from the SDJ1 borehole samples, new inferences are made regarding the recognition of the subsurface extension of the Toca da Moura Complex and its structural relationship to the Pennsylvanian continental coal-bearing SSB. These new data, together with the palynologic study of a control sample (STS15) from the Jongeis old coal mine, housed in the LNEG Geological Museum, in Lisbon, makes possible new interpretations concerning the evolution of the SSB.
\end{abstract}

(C) 2013 Published by Elsevier B.V.

\section{Contents}

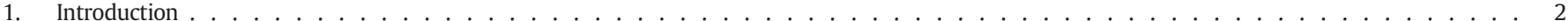

2. Geological background .. . . . . . . . . . . . . . . . . . . . . . . . . . . . . . . . . . . . . . . 2

3. Materials and methods . . . . . . . . . . . . . . . . . . . . . . . . . . . . . . . . . . . . . . . 15

4. Palynology . . . . . . . . . . . . . . . . . . . . . . . . . . . . . . . . . . . . . . . . . 15

4.1. Palynostratigraphy of the borehole SDJ1 . . . . . . . . . . . . . . . . . . . . . . . . . . . . . . . . . . . . 15

4.2. Reworked palynomorphs in SDJ1 borehole . . . . . . . . . . . . . . . . . . . . . . . . . . . . . . . . . 16

4.3. Sample from the SSB Collection of the Geological Museum (Jongeis coal mine) . . . . . . . . . . . . . . . . . . . . . . . . . . . 19

5. Provenance of the reworked palynomorphs . . . . . . . . . . . . . . . . . . . . . . . . . . . . . . . . . . . 19

6. Conclusions . . . . . . . . . . . . . . . . . . . . . . . . . . . . . . . . . . . . . . . . . . . . . . . . 21

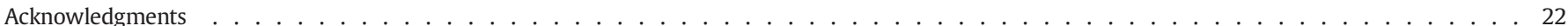

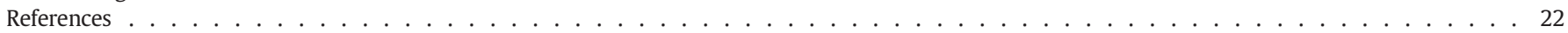

\footnotetext{
* Corresponding author. Tel.: +351220400083.
}

E-mail address: zelia.pereira@lneg.pt (Z. Pereira). 